\title{
Towards the development of a salinity impact category for South African life cycle assessments: Part 3 - Salinity potentials
}

\author{
Tony Leske* and Chris Buckley \\ Pollution Research Group, School of Chemical Engineering, University of Natal, Durban 4041, South Africa
}

\begin{abstract}
In Part 2 of this series of papers, a conceptual characterisation model was proposed for the inclusion of salinity impacts into environmental life cycle assessments. In this, the final part of the series, the results of a detailed characterisation model are presented. The methodologies used to define the "unit South African catchment" are discussed, as are the methods used to predict salt concentrations in the various compartments, from which fate factors are derived. The effect factors used in the study are presented, and in combination with the fate factors, salinity potentials are derived for emissions into the various initial release compartments. The total salinity potentials for emissions into the various initial release compartments are as follows:

Initial release compartment

Atmosphere

Surface water

Natural surfaces

Agricultural surfaces

Total salinity potential

(kg TDS equ./kg)

0.013

0.165

0.031

1.000

An additional impact category for salinity effects is therefore proposed, and the derived salinity potentials (also known as characterisation factors or equivalency factors) can be used in the classification and characterisation steps of conducting an environmental life cycle assessment to calculate the score for the impact category. The salinity potentials are only relevant to South African conditions, and their use in LCA in other countries may not be applicable. When applying the salinity potentials, the LCA practitioner should take care to prevent double accounting for certain impacts. Currently, this is simple because no equivalency factors exist for common ions, or for total dissolved salts as a lumped parameter.
\end{abstract}

Keywords: environmental life cycle assessment, salinity, characterisation model, environmental fate and effect model, equivalency factors

\section{Introduction}

The work presented in this paper stemmed out of the apparent lack of a method for incorporating salinity effects into environmental life cycle assessments, and was done to fulfil the academic requirements for the degree of doctor of philosophy at the School of Chemical Engineering, University of Natal. The reader is referred to the thesis (Leske, 2003) for detail that is too lengthy to be included in this paper.

Salination of the water resources is a well-known problem in South Africa, and is of strategic concern. Any environmental decision support tool that does not allow the evaluation of salinity effects therefore has limited applicability in the South African context. The starting point for the study was to evaluate existing impact categories, and the characterisation models used to calculate equivalency factors for these impact categories, in an attempt to incorporate salinity effects into existing categories and/or characterisation models. The types of effects of elevated (above normal background levels) dissolved salt concentrations on the natural and man-made environment were evaluated, and it was concluded that, although there was some overlap with existing impact categories, some of the salinity effects could not be described by existing impact categories. It was also concluded that there are clear and

* To whom all correspondence should be addressed.

Present address: Postnet Suite 5, Private Bag X4, Kloof 3610, South Africa 政+2783 6470015; fax: +2731 764 1025; e-mail: Tony.Leske@sappi.com Received 1 July 2003; accepted in revised form 16 January 2004. quantifiable causal relationships between interventions and salinity effects. A separate salinity impact category was therefore recommended that includes all salinity effects, including; aquatic ecotoxicity effects, damage to man-made environment, loss of agricultural production (livestock and crops), aesthetic effects and effects to natural fauna and flora (Leske and Buckley, 2003).

Once a conceptual model for a separate salinity impact category had been formulated, existing characterisation models were evaluated to determine their applicability for modelling salinity effects. Salination is a local or regional problem, and to characterise salinity effects, an environmental fate model would be required to estimate salt concentrations in the various compartments, particularly surface and subsurface water. The USES-LCA model (based on the USES 2.0 model) was evaluated because it is a well developed and accepted environmental fate model that has been adapted to calculate toxicity potentials for LCA, and would intuitively seem to be suited to be used for calculating salinity effects, some of which are toxicological in nature. It was, however, concluded that the USES-LCA model was not suitable for the calculation of salinity potentials (Leske and Buckley, 2004).

It was therefore decided to develop an environmental fate model that would overcome the limitations of The USES-LCA model, in terms of modelling the movement of salts in the environment. In terms of spatial differentiation, the same approach adopted in the USES-LCA model was adopted in developing an environmental fate model for South African conditions. This was done by defining a "unit South African catchment" (including the air volume above the catchment), which consists of an urban surface, 
TABLE 1

Summary of methodologies used to define the "unit South African catchment"

\begin{tabular}{|c|c|}
\hline Model parameter & Method used to characterise the "unit South African Catchment" \\
\hline Surface area & $\begin{array}{l}\text { The total surface area of each drainage region, the area assumed to be impervious and the areas normally } \\
\text { irrigated are given by Midgley et al. (1994). These data were used to calculate the fraction impervious (urban) } \\
\text { area and the fraction of the total rural area normally under irrigation. }\end{array}$ \\
\hline $\begin{array}{l}\text { Rainfall and } \\
\text { evaporation }\end{array}$ & $\begin{array}{l}\text { In the work presented by Midgley et al. (1994), South Africa has been divided into different rainfall and } \\
\text { evaporation zones. Rainfall and evaporation data (expressed as a percentage of mean annual precipitation) are } \\
\text { given for each rainfall and evaporation zone as well as mean annual precipitation for each catchment at } \\
\text { quaternary level. The rainfall and evaporation zone applicable to each catchment at quaternary level is } \\
\text { presented, and from this information, the average monthly rainfall and evaporation for each catchment is } \\
\text { calculated as an area weighted average. }\end{array}$ \\
\hline $\begin{array}{l}\text { WRSM90 model } \\
\text { parameters }\end{array}$ & $\begin{array}{l}\text { The model parameters used by Midgley et al. (1994) to calibrate surface water flow at quaternary catchment } \\
\text { level were regionalised by calculating area weighted average parameter values for each drainage region, and } \\
\text { for the "unit catchment". }\end{array}$ \\
\hline River flow & $\begin{array}{l}\text { Simulated natural monthly river flow data are presented by Midgley et al. (1994) at secondary catchment level. } \\
\text { The natural monthly river flow was decreased to account for stream flow reduction due to forestry; using the } \\
\text { fraction that runoff is decreased due to forestry (taken from DWAF, 1996). The total river flow was then } \\
\text { calculated by summing the flows from each secondary catchment. }\end{array}$ \\
\hline River losses & $\begin{array}{l}\text { Channel bed losses and losses due to wetlands are reported by Midgley et al (1994) at quaternary catchment } \\
\text { level and were used to calculate channel losses for the "unit river". }\end{array}$ \\
\hline Irrigation factors & $\begin{array}{l}\text { Rainfall, evaporation and irrigation data from Schulze et al. (1997) were used to back-calculate the irrigation } \\
\text { demand factor. }\end{array}$ \\
\hline Surface water quality & $\begin{array}{l}\text { Water quality data were obtained from the Water Quality on Disc database, provided by the Directorate of } \\
\text { Hydrology and the Institute for Water Quality Studies. The database contains data up to the end of September } \\
\text { 1999. The method for calculating the average total dissolved salt concentration in the "unit river" is described } \\
\text { in detail in Leske (2003). Briefly, however, water quality data for the gauging station closest to the primary } \\
\text { catchment outlet were used for a year in which the data set for the gauging station was most complete. } \\
\text { Regression analysis was then used to estimate the quality at a common year (2000) for all rivers. The total salt } \\
\text { load in all rivers was added, and the flow of the "unit river" was used to calculate average salt concentrations } \\
\text { for the "unit river". }\end{array}$ \\
\hline
\end{tabular}

rural agricultural soil (and associated soil moisture), rural natural soil (and associated moisture), groundwater (natural and agricultural) and a river with a flow equal to the sum of the flows of all rivers in South Africa, and a concentration equal to the average concentration of each river in the country. A non-steady state environmental fate model (or, hydrosalinity model) was developed, and the methodology followed in the development of the model. The model results are presented in this paper. The model can predict environmental concentrations at a daily time-step in all the compartments relevant to the calculation of salinity potentials, and includes all the major processes governing the distribution of common ions in the various compartments. The predicted environmental concentrations are used in conjunction with no-effect concentrations to derive salinity potentials. The no-effect concentrations are based on the target water quality ranges given in the South African Water Quality Guidelines (DWAF, 1996).

\section{Defining the "unit South African catchment"}

Data presented by Midgley et al. (1994) were used to characterise the surface water resources of the "unit South African catchment".
South Africa is divided into 22 drainage regions. Each drainage region is subdivided into primary drainage regions, which in turn are subdivided into secondary, tertiary and quaternary subcatchments. Average monthly rainfall and evaporation data are presented for each drainage region at quaternary sub-catchment level. Simulated monthly surface water flows are calculated (Midgley et al., 1994) at secondary catchment level using a modified version of the model originally developed by Pitman (1973), known as the WRSM90 model. Table 1 contains a brief summary of the methodology used to characterise the "unit South African catchment". Detailed descriptions of the methodology used is given in Leske (2003).

\section{Environmental fate model}

The fate model developed consists of two distinct submodels; the atmospheric deposition model is essentially a separate submodel of the fate model, inasmuch as the output from the model is the daily salt deposition rate, which is the only parameter that affects the salt concentrations in other compartments of the model. The model can therefore be calibrated separately. The second submodel is termed 
the hydrosalinity model, which in turn consists of two components. The catchment hydrology component models the movement and storage of surface, soil and groundwater throughout the catchment, and the salt transport component models the movement and storage of salt throughout the catchment, including salt adsorption. The hydrological component can also be calibrated separately since the movement of water throughout the various compartments making up the catchment does not change from year to year, and observed surface water flows can be used to calibrate this component of the model. The fate model was programmed using Visual Basic 6.0.

\section{Atmospheric deposition model}

The approach adopted was to develop a simple "fixed-box" (De Nevers, 1995) atmospheric deposition model that could predict salt deposition rates at a daily time step, without resorting to complex air dispersion modelling, with its associated data demand. Deposition mechanisms are modelled in a similar way to Herold et al. (2001). The conceptual atmospheric model is shown schematically in Fig. 1. The total air volume is divided into a rural air volume, and an urban air volume that is totally bounded by the rural air volume.

The major simplifying assumptions made include:

- Atmospheric turbulence in both the urban and rural air volumes produces complete mixing up to the mixing height.

- The density of the atmosphere up to the mixing height is constant, and the mixing height is constant.

- All matter entering the air volumes and/or generated within the volumes is contained below the mixing height, and no matter leaves through the sides that are parallel to the direction of the wind.

- The aerosol soluble inorganic mass fraction remains constant and is the same for the urban and rural air volumes.

- The emission of pollutant into the air occurs into the urban air volume.

- Wind does not change direction, and is independent of location and elevation.

The above assumptions are clearly a great simplification of what really occurs in nature. The worst assumption is that the air volumes are completely mixed (De Nevers, 1995). In reality, concentration gradients will exist that depend on very many variables, including local meteorological conditions, topography, and so on. The desired output from the atmospheric deposition model, in terms of the overall fate model, is the total daily salt deposition rate. This is the only output from the atmospheric deposition model that is used as input by the hydrosalinity model. More complicated air dispersion models exist that have a very high model parameter demand, and can generally only be applied to limited geographical scales, for which the topography and meteorological conditions are known. The simplifying assumptions made, although not ideal, allow estimates to be made of deposition rates at a daily time-step using comparatively few parameters.
By applying the simplifying assumptions, and conducting a mass balance, the concentrations in the urban and rural air volumes can be calculated, from which the urban and rural deposition rates are calculated.

The parameters used in the atmospheric deposition model, as well as the calibrated values of these parameters are shown in Table 2. The modelled total daily deposition rate on urban and rural surfaces is depicted in Fig. 2. Although deposition rates are calculated at a daily time-scale, it is not possible to calibrate the model on a daily time-scale, since daily data are not available. The approach adopted to "calibrate" the model was to use published values for the model parameters shown in Table 2, and then to adjust the anthropogenic aerosol generation rate (this is the most sensitive parameter) until the following model results were within the same order of magnitude as published values (usually isolated measurements):

- Total aerosol deposition.

- Aerosol concentration.

- Rainwater composition.

The anthropogenic aerosol generation rate was adjusted to give the model outputs shown in Table 3. Values of 0.04 and $0.4 \mathrm{t} / \mathrm{km}^{2} \cdot \mathrm{d}$ for rural and urban anthropogenic aerosol generation rates respectively resulted in the outputs shown.

The model outputs (Table 3) fall within the ranges of the limited published data, except for the urban aerosol deposition rate, which the model appears to over predict. The deposition data reported by Tyson and Gatebe (2001) and DWAF (1995) for total aerosol deposition, and the data presented by Coleman (1993) appear to be contradictory, however. Based on the data presented by Coleman (1993), the total aerosol deposition rate would be expected to be significantly higher, considering that only a fraction (approxi- 
TABLE 2

Model parameters used in the atmospheric deposition model compared to published values

\begin{tabular}{|c|c|c|c|c|c|}
\hline Parameter & Units & $\begin{array}{l}\text { Published } \\
\text { value * }\end{array}$ & $\begin{array}{l}\text { Value used in model } \\
\text { Comments }\end{array}$ & Reference & \\
\hline $\begin{array}{l}\text { Aerosol deposition } \\
\text { velocity (summer) }\end{array}$ & $\mathrm{cm} / \mathrm{s}$ & $\begin{array}{l}-(0.3)-6.61 \\
-(1.3)-\end{array}$ & $\begin{array}{l}\text { For } \mathrm{SO}_{2} \\
\text { Grasslands }\end{array}$ & $\begin{array}{l}\text { Herold et al. (2001) } \\
\text { Skorosweski (1999) }\end{array}$ & 1.3 \\
\hline $\begin{array}{l}\text { Aerosol deposition } \\
\text { velocity (winter) }\end{array}$ & $\mathrm{cm} / \mathrm{s}$ & $\begin{array}{l}-(0.28)-0.15 \\
-(0.3)-\end{array}$ & $\begin{array}{l}\text { For } \mathrm{SO}_{2} \\
\text { Grasslands }\end{array}$ & $\begin{array}{l}\text { Herold et al. (2001) } \\
\text { Skorosweski (1999) }\end{array}$ & 0.3 \\
\hline $\begin{array}{l}\text { Annual deposition } \\
\text { velocity }\end{array}$ & $\mathrm{cm} / \mathrm{s}$ & $\begin{array}{c}0.3-(\text { )-2.3 } \\
-(0.8)- \\
0.11-(0.18)-0.22 \\
0.54-(0.58)-0.63\end{array}$ & $\begin{array}{l}\text { For } \mathrm{SO}_{2} \\
\text { Eastern Transvaal Highveld } \\
\text { England - continental aerosols } \\
\text { England - marine aerosols }\end{array}$ & $\begin{array}{l}\text { Skorosweski (1999) } \\
\text { Skorosweski (1999) } \\
\text { Bridgman (1990) } \\
\text { Bridgman (1990) }\end{array}$ & - \\
\hline $\begin{array}{l}\text { Dry deposition factor } \\
\text { (summer) }\end{array}$ & - & -(1.09)- & For $\mathrm{SO}_{2}$ & Herold et al. (2001) & 1.09 \\
\hline $\begin{array}{l}\text { Dry deposition factor } \\
\text { (winter) }\end{array}$ & - & $-(1.07)-$ & For $\mathrm{SO}_{2}$ & Herold et al. (2001) & 1.07 \\
\hline Occult deposition factor & - & $-(0.025)-$ & For $\mathrm{SO}_{2}$ & Herold et al. (2001) & 0.025 \\
\hline $\begin{array}{l}\text { Atmospheric mixing } \\
\text { height }\end{array}$ & $\mathrm{m}$ & $-(1950)-$ & $700 \mathrm{hPa}$ & Piketh et al. (1999) & 1950 \\
\hline Wash ratio & - & $1 \times 10^{5}-()-1.4 \times 10^{6}$ & & Huijbregts (1999) & $7.5 \times 10^{5}$ \\
\hline Fraction salt in aerosol & - & $\begin{array}{c}-(2 \times 105)- \\
0.4-()-0.8 \\
0.71-()-0.74\end{array}$ & $\begin{array}{l}\text { For sulphate } \\
\text { Kruger National Park } \\
\text { Urban area }\end{array}$ & $\begin{array}{l}\text { Skorosweski (1999) } \\
\text { Maenhaut et al. (1996) } \\
\text { Coleman (1993) }\end{array}$ & 0.6 \\
\hline $\begin{array}{l}\text { Concentration of aerosol } \\
\text { entering rural air volume } \\
\text { from upstream }\end{array}$ & $\mathrm{mg} / \mathrm{m}^{3}$ & $\begin{array}{c}\text {-(13)- } \\
9-()-19 \\
-(10)- \\
0.4-(2.2)-9.3\end{array}$ & $\begin{array}{l}\text { Kruger National Park } \\
\text { Rural areas of eastern S. Africa } \\
\text { Africa }\end{array}$ & $\begin{array}{l}\text { Hewitt and Sturges (1993) } \\
\text { Maenhaut et al. (1996) } \\
\text { Tyson et al. (1996) } \\
\text { Anderson et al. (1996) }\end{array}$ & 15 \\
\hline $\begin{array}{l}\text { Natural aerosol generation } \\
\text { rate }\end{array}$ & $\mathrm{kg} / \mathrm{km}^{2} \cdot \mathrm{d}$ & $1.5 \times 10^{-5}-()-1.5 \times 10^{-4}$ & Global average & Hewitt and Sturges (1993) & $1.3 \times 10^{-5}$ \\
\hline $\begin{array}{l}\text { Urban anthropogenic } \\
\text { aerosol generation rate }\end{array}$ & $\mathrm{t} / \mathrm{km}^{2} \cdot \mathrm{d}$ & $0.0037-()-0.0092$ & Global average & Hewitt and Sturges (1993) & 0.4 \\
\hline $\begin{array}{l}\text { Rural anthropogenic } \\
\text { generation rate }\end{array}$ & $\mathrm{t} / \mathrm{km}^{2} \cdot \mathrm{d}$ & $0.0037-()-0.0092$ & Global average & Hewitt and Sturges (1993) & 0.04 \\
\hline
\end{tabular}

mately 0.6) of the aerosol is soluble.

A model parameter sensitivity analysis was conducted. The rural anthropogenic aerosol generation rate was the most sensitive parameter, followed by the natural aerosol generation rate and summer deposition velocity.

\section{Catchment hydrology component of the hydrosalinity model}

Numerous hydrosalinity models have been developed and applied to various studies of South African catchments. These models range from simple models requiring very few input parameters to complex three-dimensional groundwater and solute-transport models that require a large number of input parameters (Hughes, 1997).

The simple methodology used in the USES-LCA model is inadequate to describe salinity effects (Leske and Buckley, 2004). At the other extreme, however, more complex models would require many more parameters, which are often not known for particular catchments within the country, and are certainly not known for a "regionalised catchment". A compromise was therefore sought between these two extremes. The hydrosalinity model developed by Herold (1981), and originally based on the work by 


\begin{tabular}{|c|c|c|c|c|c|c|c|}
\hline \multicolumn{8}{|c|}{$\begin{array}{c}\text { TABLE } 3 \\
\text { Summary of atmospheric deposition model outputs compared to published values }\end{array}$} \\
\hline \multirow[t]{2}{*}{ Parameter } & \multirow[t]{2}{*}{ Units } & \multirow{2}{*}{$\begin{array}{l}\text { Published } \\
\text { value * }\end{array}$} & \multicolumn{5}{|l|}{ Model outputs } \\
\hline & & & Comments & Reference & Urban & Rural & $\begin{array}{l}\text { Com- } \\
\text { bined }\end{array}$ \\
\hline $\begin{array}{l}\text { Total aerosol } \\
\text { deposition }\end{array}$ & $\mathrm{kg} / \mathrm{ha} \cdot \mathrm{yr}$ & $\begin{array}{l}-(208)- \\
-(317)- \\
-(215)-\end{array}$ & $\begin{array}{l}\text { South Africa } \\
\text { Urban (Pinetown, South Africa) } \\
\text { Residential (Durban, South Africa) }\end{array}$ & $\begin{array}{l}\text { Tyson and Gatebe (2001) } \\
\text { DWAF (1995 }\end{array}$ & 773 & 267 & 273 \\
\hline $\begin{array}{l}\text { Total aerosol } \\
\text { (soluble) salt } \\
\text { deposition }\end{array}$ & $\mathrm{kg} / \mathrm{ha} \cdot \mathrm{yr}$ & $\begin{array}{c}(193) \\
0-(412)-1836 \\
16-(1059)-3011\end{array}$ & $\begin{array}{l}\text { Urban (Pinetown, South Africa) } \\
\text { Urban (South Africa) } \\
\text { Urban (South Africa) }\end{array}$ & Coleman (1993) & 464 & 160 & 165 \\
\hline Rainfall TDS & $\mathrm{mg} / \ell$ & $\begin{array}{l}20-()-104 \\
0.9-(10)-61\end{array}$ & $\begin{array}{l}\text { Urban (South Africa) } \\
\text { Suikerbos Natural Reserve (South } \\
\text { Africa): Winter }\end{array}$ & $\begin{array}{l}\text { Coleman (1993) } \\
\text { Skoroszewski (1999) }\end{array}$ & 44 & 18 & 31 \\
\hline $\begin{array}{l}\text { Aerosol } \\
\text { concentration }\end{array}$ & $\mathrm{mg} / \mathrm{l}$ & $\begin{array}{l}20-()-80 \\
26-()-33 \\
9-()-19 \\
-(20)-120 \\
-(15)-140 \\
-(10)-60\end{array}$ & $\begin{array}{l}\text { Ben MacDhui, } 4 \mathrm{~km} \text { stable } \\
\text { layer (South Africa) } \\
\text { Several locations throughout } \\
\text { South Africa } \\
\text { Kruger National Park (South Africa) } \\
\text { Johannesburg (South Africa) } \\
\text { Eastern Transvaal Highveld (South } \\
\text { Africa) } \\
\text { Rural eastern South Africa }\end{array}$ & $\begin{array}{l}\text { Tyson and Gatebe (2001) } \\
\text { Picketh et al. (1999) } \\
\text { Maenhaut et al. (1996) } \\
\text { Tyson et al. (1996) }\end{array}$ & 97 & 39 & 68 \\
\hline
\end{tabular}

Pitman (Pitman, 1973 and Pitman, 1976) is deemed to be the best compromise. A modified version of the Pitman model has become the most widely used monthly time-step, rainfall-runoff model within southern Africa. The current official version of the model is referred to as WRSM90, and was used to model rainfall-runoff in all catchments within South Africa to the quaternary catchment level (Midgely et al., 1994). Monthly simulated natural river flow data is therefore available for all catchments in the country, as are many of the model parameters used. The rainfall-runoff component of the model initially developed by Pitman (1973) and later modified by Herold (1981) is essentially used as presented by Herold (1981). Only minor simplifications were made to the model. The model parameters used, and the calibrated parameter values are shown in Table 4.

The cachment hydrology component of the model was calibrated against the observed (or calculated, for the "unit catchment") average monthly river flows (shown in Fig. 3). The criteria used to measure correlation were the correlation coefficient $\left(r^{2}\right)$ and the Agreement Index (Moolman, 1993).

The results of a parameter sensitivity analysis indicate that, in terms of the change in Agreement Index over the range in which the parameters were adjusted, the nominal maximum infiltration rate is the most sensitive parameter followed by the interception storage and percolation at soil moisture capacity. More detailed sensitivity analyses of the hydrological component of the model parameters can be found in Leske (2003), Herold (1981) and Moolman (1993).

The modelled daily soil moistures and the daily river flow for the "unit catchment" over a one-year cycle are shown in Figs. 4 and 5 respectively. The impact of irrigation on the soil moisture profile in the rural agricultural soil evident from Fig. 4.

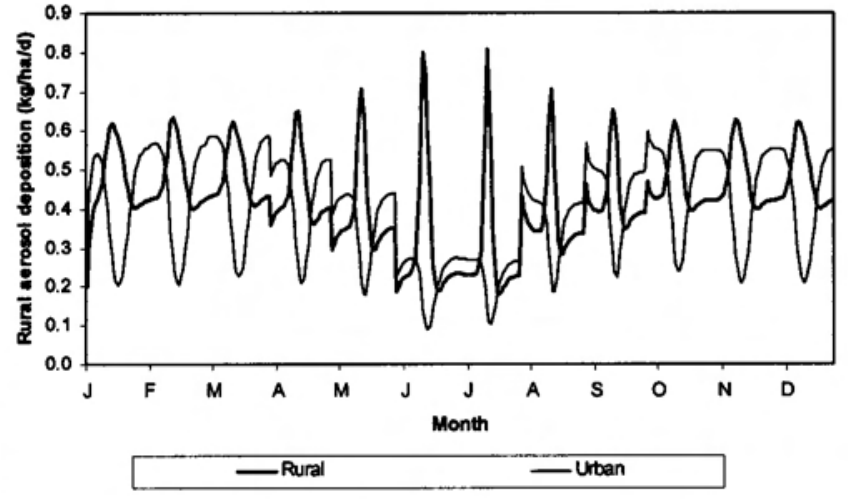

Figure 2

Modelled daily deposition rate over a one-year period

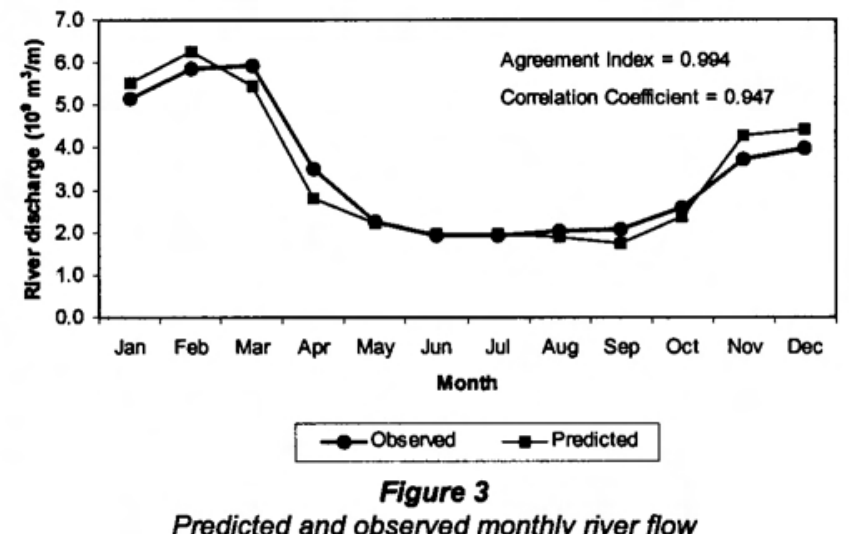

Predicted and observed monthly river flow 
TABLE 4

Calibrated catchment hydrology model parameter values

\begin{tabular}{|c|c|c|}
\hline Model Parameter & Value & Units \\
\hline Catchment area & $1.66 \times 10^{12}$ & $\mathrm{~m}^{2}$ \\
\hline Catchment length & 1289194 & $\mathrm{~m}$ \\
\hline Fraction urban area & 0.00034 & - \\
\hline Fraction rural area under irrigation & 0.00034 & - \\
\hline $\begin{array}{l}\text { Proportion of catchment runoff draining to the } \\
\text { upstream end of the river }\end{array}$ & 0.1 & - \\
\hline River width & 1000 & $\mathrm{~m}$ \\
\hline River slope & 0.001 & $\mathrm{~m} / \mathrm{m}$ \\
\hline River length & 1000000 & $\mathrm{~m}$ \\
\hline River evaporation factor & 0.9 & - \\
\hline River bedloss & 3.7 & $\mathrm{~mm} / \mathrm{d}$ \\
\hline River Manning factor & 0.065 & - \\
\hline First constant in rainfall duration relationship & 0.964 & $\mathrm{~h}$ \\
\hline Second constant in rainfall duration relationship & 0.137 & $\mathrm{~h} / \mathrm{mm}$ \\
\hline Power of soil moisture-percolation relationship & 0.65 & - \\
\hline Soil moisture below which no percolation occurs & 0.004 & $\mathrm{~mm}$ \\
\hline Soil moisture capacity & 107 & $\mathrm{~mm}$ \\
\hline Percolation at soil moisture capacity & 0.11 & $\mathrm{~mm} / \mathrm{h}$ \\
\hline Nominal minimum infiltration rate & 0.31 & $\mathrm{~mm} / \mathrm{h}$ \\
\hline Nominal maximum infiltration rate & 3.30 & $\mathrm{~mm} / \mathrm{h}$ \\
\hline Interception loss & 1.05 & $\mathrm{~mm}$ \\
\hline Routing constant for surface runoff & 0.183 & $\mathrm{~d}$ \\
\hline Recession constant for groundwater depletion & 0.09 & d \\
\hline Coefficient of evaporation-soil moisture relationship & 0.14 & - \\
\hline Soil moisture below which no evaporation occurs & 0 & $\mathrm{~mm}$ \\
\hline Lag period for surface runoff & 0 & $\mathrm{~d}$ \\
\hline Proportion of groundwater entering deep groundwater & 0 & - \\
\hline Maximum proportion of surface runoff from interflow & 0.8 & - \\
\hline
\end{tabular}
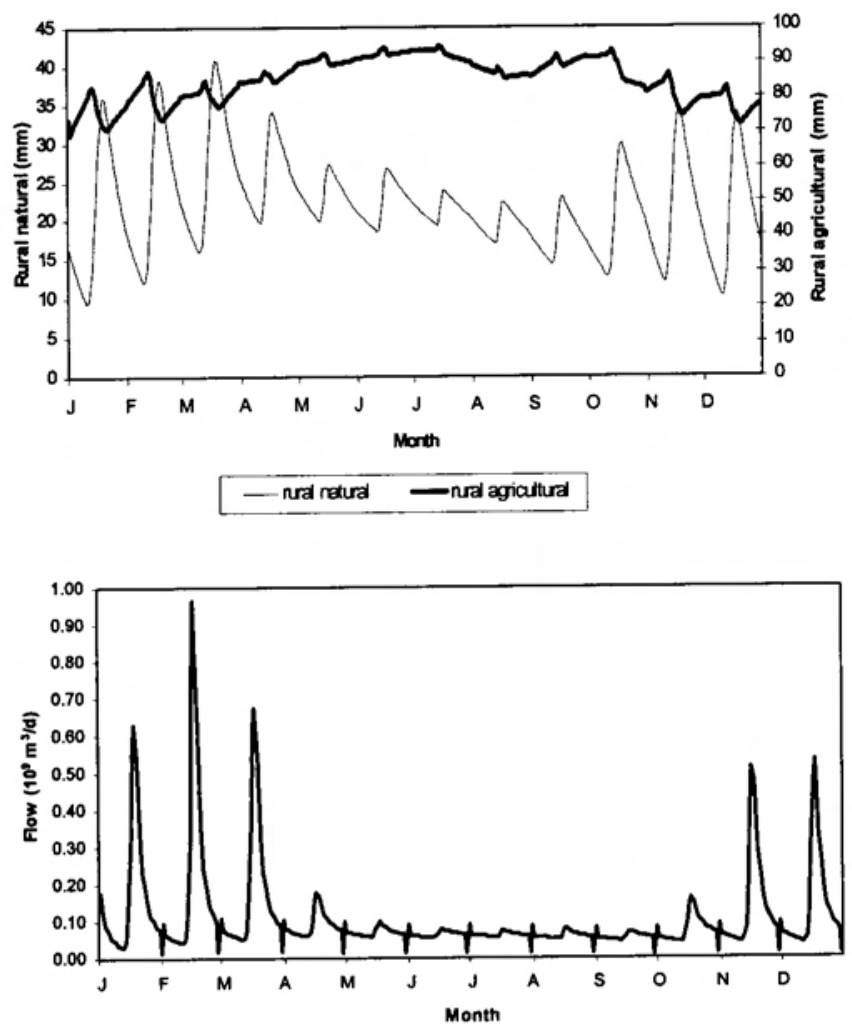
is not as good as was achieved with the river flows. Further adjustment of the parameters did not yield better results, and it is likely that this is partly due to the lack of surface water quality data in some catchments.

The salt concentrations shown in Fig. 6 appear to be high, for an average South African river. The salt loads from drainage regions $\mathrm{G}$ and $\mathrm{K}$ together constitute $49 \%$ of the total annual load in the "unit river", due to the high natural salinity in these drainage regions. Their combined flow, however, only constitute $6.5 \%$ of the total annual flow in the "unit river". If the average concentrations in the rivers in drainage regions $\mathrm{G}$ and $\mathrm{K}$ are set equal to those of drainage regions adjacent to these (E and J respectively), then the adjusted concentration values for the "unit river" are more typical for an "average South African river". It was decided, however, to calibrate the model using the unadjusted values. Calibration of the model using adjusted values could be achieved by adjusting the surface salt generation rate, which would not influence the values of the fate factors, and therefore the salinity potentials.

The results of a parameter sensitivity analysis indicated that, in terms of the change in Agreement Index over the range in which the parameters were adjusted, the rural natural salt generation rate is

Figure 4 (top left)

Modelled daily soil moisture over a one-year cycle

Figure 5 (bottom left)

Modelled daily river flow over a one-year cycle 


\begin{tabular}{|l|c|c|}
\hline \multicolumn{3}{|c|}{ TABLE 5 } \\
\hline \multicolumn{3}{|c|}{ Salt transport model parameters } \\
\hline Model parameter & Symbol & Units \\
\hline Urban surface wash-off parameter & 0.0085 & $1 / \mathrm{mm}$ \\
Rural natural surface wash-off parameter & 0.00085 & $1 / \mathrm{mm}$ \\
Rural agricultural surface wash-off parameter & 0.0009 & $1 / \mathrm{mm}$ \\
Solubility limit & 50 & $\mathrm{~kg} / \mathrm{m}^{3}$ \\
Salt leach rate & $3.5 \mathrm{x} 10^{-6}$ & $\mathrm{~kg} / \mathrm{m}^{3} \cdot \mathrm{d}$ \\
First Langmuir adsorption constant & 0.000024 & $\mathrm{~kg} / \mathrm{kg}$ \\
Second Langmuir adsorption constant & 0.418 & $\mathrm{~kg} / \mathrm{m}^{3}$ \\
Soil void fraction & 0.5 & - \\
Soil density & 1200 & $\mathrm{~kg} / \mathrm{m}^{3}$ \\
Urban anthropogenic salt generation rate & 0.7 & $\mathrm{t} / \mathrm{km}^{2} \cdot \mathrm{y}$ \\
Rural natural anthropogenic salt generation rate & 0.047 & $\mathrm{t} / \mathrm{km}^{2} \cdot \mathrm{y}$ \\
Rural agricultural anthropogenic salt generation rate & 0.5 & $\mathrm{t} / \mathrm{km}^{2} \cdot \mathrm{y}$ \\
\hline
\end{tabular}
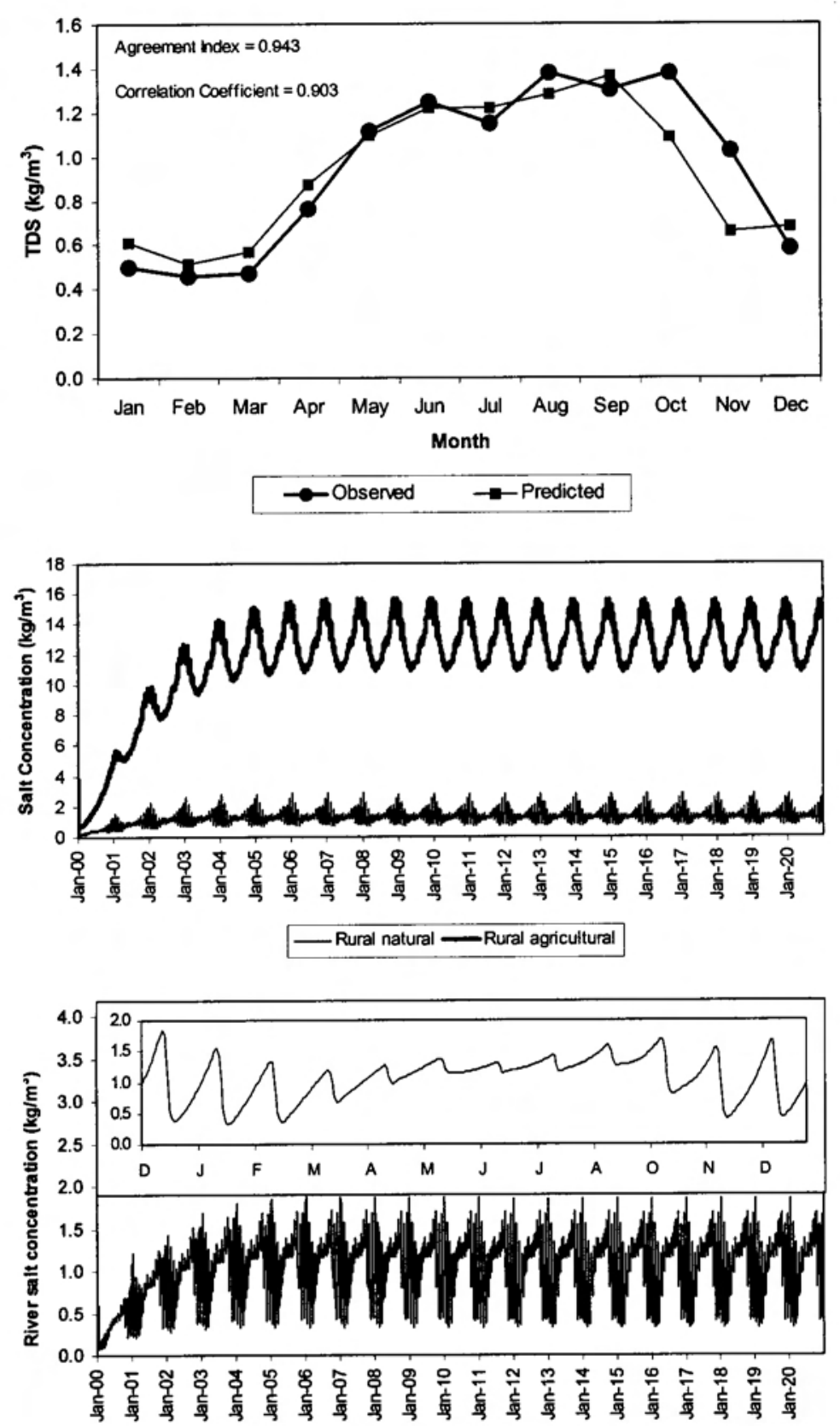

the most sensitive parameter followed by the solubility limit.

Salts are modelled as a lumped parameter, and there is therefore no solubility limit for total dissolved salts per se. The approach adopted was to vary the "solubility limit" and evaluate the effect on the model results.

The modelled daily salt concentration in the soil moisture for a 20-year simulation is shown in Fig. 7. The effect of the concentration effect caused by irrigation is evident in Fig. 7. The modelled daily salt concentration in the river for a 20 -year simulation is shown in Fig. 8. The insert in Fig. 8 shows the daily salt concentration in the river for the last year of the simulation.

\section{Sediment component of hydrosalinity model}

The parameters used to model sediment generation and transport are given in Table 6. The values of the model parameters shown in Table 6 (except the constants in the river flow-suspended sediment relationship) are values recommended by Paling et al. (1989). The constants for the river flow-suspended sediment relationship were taken from Pye (1994). The parameter values were varied by $\pm 50 \%$, and the effect on the river concentration Agreement Index determined. No significant difference in Agreement Index was observed. This is due to the small contribution that adsorbed salt has to total salt transport. Adsorbed salt comprises $0,04 \%$ of the total salt load from surface runoff, and $0.001 \%$ of the total salt load in the river. Due to the insignificant role that salt adsorbed onto sediments has on the overall salt balance, the parameters shown in Table 6 were accepted as being adequate without further adjustment.

\section{The sensitivity of fate factors to model parameters}

The method for calculating effects potentials for salinity impacts is given by Leske and Buckley (2003) and the general equation is given by:

Effects Potential $=$ Fate Factor $x$ Effect Factor

where:

$$
\begin{aligned}
& \text { Fate Factor }=\frac{\sum_{i=1}^{N}\left[P E C_{i}-P E C_{i}^{0}\right] \Delta t}{M} \\
& \text { Effect Factor }=\frac{1}{P N E C}
\end{aligned}
$$

Figure 6 (top left)

Predicted and observed monthly river total dissolved salts concentration

Figure 7 (middle left)

Modelled soil moisture salt concentration for a 20-year simulation

Figure 8 (bottom left)

Modelled daily river salt concentration for a 20-year simulation 


\begin{tabular}{|c|c|c|}
\hline \multicolumn{3}{|l|}{$\begin{array}{c}\text { TABLE } 6 \\
\text { Sediment model parameters }\end{array}$} \\
\hline Model parameter & Units & Value \\
\hline Catchment cover density & - & 0.8 \\
\hline Sediment detachment coefficient & $\mathrm{N} / \mathrm{mm}^{2}$ & 0.0138 \\
\hline Erosivity factor & $\mathrm{kg} / \mathrm{N} \cdot \mathrm{m}^{2}$ & 0.5 \\
\hline Loose soil density & $\mathrm{kg} / \mathrm{m}^{3}$ & 1500 \\
\hline Sediment diameter & $\mathrm{mm}$ & 0.2 \\
\hline Sediment specific gravity & - & 2.65 \\
\hline First constant in suspended sediment-river flow relationship & - & 20 \\
\hline Second constant in suspended sediment-river flow relationship & - & 0.3 \\
\hline
\end{tabular}

assessment factors. No additional assessment factors are therefore applied to the target water quality ranges.

\section{Aquatic ecotoxicity}

Plants and animals possess a wide range of physiological mechanisms and adaptations to maintain the necessary balance of water and dissolved ions in cells and tissues. This ability is extremely important in any consideration of the effects of changes in total dissolved salts on aquatic organisms. The individual ions making up the total dissolved salts also exert physiological effects on aquatic organisms. Changes in concentration of the total dissolved salts can affect aquatic organisms at

Fate factors are calculated for each compartment relevant to salinity effects (soil moisture and surface water compartments), for emissions into each initial release compartment (air, soil and surface water).

The parameter values influence the correlation between observed and predicted concentrations and some parameters influence this correlation more than others. Some parameters in fact influence the values of the fate factors, and again, some parameters more than others. It is therefore important that the correct values for these parameters be chosen to calibrate the model.

The six most sensitive parameters, in terms of their influence on the correlation between observed and predicted values were evaluated to determine the sensitivity of the fate factors to these parameters. This was done by running a number of 20 -year simulations (2000 to 2020) of the environmental fate model using different values of the selected parameters, with and without an imposed impulse emission into the various initial release compartments. An impulse magnitude of $1 \times 10^{8} \mathrm{~kg}$ of 1 -year duration, starting on 1 January 2002 was used as the basis for comparison.

The results of the analysis showed that some model parameters (particularly those that influence the distribution of surface and subsurface flow) influence the values of the fate factors (and therefore the salinity potentials). The implicit assumption is however that if there is a good correlation between the observed and predicted values, then the resulting fate factors will be correct.

\section{Effects assessment}

The effects potential was defined (Eq. (1)) as the product of a fate factor and an effect factor, the effect factor being the reciprocal of the predicted no-effect concentration (or PNEC). In principle, the PNEC is calculated by dividing the lowest short-term $\mathrm{LC}_{50}$ (concentration at which $50 \%$ of the test organisms die) or long-term NOEC (no observed effect concentration) by an appropriate assessment factor. The assessment factors reflect the degree of uncertainty in extrapolating from laboratory toxicity test data for a limited number of species to the "real" environment. Assessment factors applied for long-term results are smaller as the uncertainty of extrapolation from laboratory data to the natural environment is reduced (EC, 1996).

In this study, the South African Water Quality Guidelines (DWAF, 1996) were used as a basis for determining no-effect concentrations. The guidelines specify a target water quality range, within which no measurable adverse effects are expected for longterm continuous use. The target water quality ranges quoted in the South African Water Quality Guidelines (DWAF, 1996) have been derived from quantitative and qualitative criteria, and include

three levels, namely:

- effects on, and adaptations of, individual species

- effects on community structure

- effects on microbial and ecological processes such as rates of metabolism and nutrient cycling.

The rate of change of the total dissolved salts concentration, and duration of change, appears to be more important than absolute changes in the total dissolved salts concentration, particularly in systems where the organisms may not be adapted to fluctuating levels (DWAF, 1996).

The South African Department of Water Affairs and Forestry guidelines for the impact of total dissolved salts on aquatic ecosystems are as follows:

- Total dissolved solids concentrations should not be changed by more than $15 \%$ from the normal cycles of the water body under unimpacted conditions at any time of the year.

- The amplitude and frequency of natural cycles in total dissolved solids concentrations should not be changed.

In view of the above, no single value is used for the aquatic ecotoxicity no-effect concentration. The no-effect concentrations are calculated as a function of the background salt concentration. The aquatic ecotoxicity effects potential (AEEP) is therefore calculated as follows:

$$
A E E P_{\text {irc }}=\frac{\sum_{i=1}^{N}\left[P E C_{i}^{R}-P E C_{i}^{R, 0}\right] \Delta t}{1.15 P E C_{i}^{R, 0} M^{R}}
$$

\section{Livestock production}

Guidelines for the effects of total dissolved salts on livestock, issued by the South African Department of Water Affairs and Forestry (DWAF, 1996) are published for various different types of livestock. A no-effect concentration of $1 \mathrm{~kg} / \mathrm{m}^{3}$ was used to calculate salinity potentials.

\section{Agricultural crops}

Crop yield loss is directly related to total dissolved salts concentration above a certain threshold concentration. Threshold and yield loss relationships for many species of plans are published in the literature. In the literature reviewed, the crops most sensitive to 
salinity are beans and carrots, with threshold concentrations of $0.455 \mathrm{~kg} / \mathrm{m}^{3}$, and this value was used to calculate salinity potentials.

\section{Damage to man-made environment}

The norms used by the South African Department of Water Affairs and Forestry to measure the suitability of water supply, in terms of the presence of dissolved salts are (DWAF, 1996):

- the extent of damage caused to equipment and structures as a result of dissolved salts

- the extent to which the dissolved solids in the water supply interfere with industrial processes

- the extent of impairment of product quality caused by the presence of dissolved salts

- the degree of complexity involved in the treatment and/or disposal of wastes generated as a result of the presence of dissolved salts.

The Department of Water Affairs and Forestry have defined four categories of processes according to the degree to which they are affected by the presence of dissolved salts. Category 1 processes require high quality water, while Category 4 processes require low quality water.

Within the target water quality ranges, no effects on equipment and structures, interference with processes, product quality and complexity of waste treatment are expected at concentrations below $0.1 \mathrm{~kg} / \mathrm{m}^{3}$, and this value was used to calculate salinity potentials.

\section{Natural vegetation}

No data are available on the effect of dissolved salts on natural vegetation in South Africa. Most riparian plants in Australia can tolerate salinities greater than $5 \mathrm{~kg} / \mathrm{m}^{3}$, and sensitive species will only be adversely affected by salinities above $2 \mathrm{~kg} / \mathrm{m}^{3}$. In the United States is has been proposed that, for the protection of wildlife habitats, salinity should not vary by more than $1 \mathrm{~kg} / \mathrm{m}^{3}$ in water where the natural salinity is below $3.5 \mathrm{~kg} / \mathrm{m}^{3}$ (WRC, 2000b). Threshold salinity limits for 27 different grasses and forage crops are reported by Maas (1990). Values vary from $0.98 \mathrm{~kg} / \mathrm{m}^{3}$ to $4.49 \mathrm{~kg} / \mathrm{m}^{3}$, with an average of $2.15 \mathrm{~kg} / \mathrm{m}^{3}$. A value $0.98 \mathrm{~kg} / \mathrm{m}^{3}$ was used to calculate effects potentials.

\section{Wildlife}

Originally it was thought that salinities might have an effect on the productivity and reproductive capacity of wildlife. At high $\left(>3 \mathrm{~kg} / \mathrm{m}^{3}\right)$ salinities this may be the case for the more sensitive animals, but at salinities below $1.2 \mathrm{~kg} / \mathrm{m}^{3}$ there will be no real effect on animals and birds. Drinking water criteria for livestock and poultry are acceptable as criteria for wildlife (WRC, 2000b). A value of $1.2 \mathrm{~kg} / \mathrm{m}^{3}$ was used to calculate salinity potentials.

\section{Aesthetic effects}

The South African water quality guidelines (DWAF, 1996) indicate that no aesthetic effects, effects on human health, household distribution systems and water heating appliances occur at a salt concentration of less than $0.45 \mathrm{~kg} / \mathrm{m}^{3}$, and this value was used to calculate salinity potentials.

Aesthetic effects generally encompass taste, odour and colour.
Dissolved salts do not impart colour or odour to water, and therefore the no-effect concentration for aesthetic effects is for taste only.

\section{Salinity potentials}

The life-cycle inventory stage of a life-cycle assessment results in a list of substances released into the environment and the total mass of these substances released, in other words, an impulse emission. The temporal and spatial distribution of the impulse emission is generally unknown. Spatial distribution is taken into account in the model developed, by defining a "unit South African catchment". The resulting salinity potentials are therefore only relevant to the catchment, as defined. Regarding temporal distribution, the date on which the impulse emission starts, and the duration of the impulse is generally not known. The analysis presented below will demonstrate that this information is not required for the calculation of salinity potentials.

\section{The effect of impulse characteristics on salinity potentials}

The effect that impulse characteristics (magnitude, duration, starting date) have on salinity potentials is discussed below.

\section{Impulse magnitude}

Firstly, the linearity of the salinity potentials needs to be confirmed. In other words, the value of the salinity potential due to a release of $y \mathrm{~kg}$ of salt into the environment should be half the value if $2 y \mathrm{~kg}$ is released into the environment.

A number of 20-year simulations were done with varying impulse magnitudes into the initial release compartments. The results indicate that the salinity potentials are a linear function of impulse magnitude up to an impulse magnitude of $1 \times 10^{8}$, but at higher impulse magnitudes this is not the case. At higher impulse magnitudes, the solubility limit in the rural agricultural soil moisture was exceeded. Once the solubility limit has been exceeded, the salt concentration in the soil moisture remains constant (at the value of the solubility limit) until sufficient water has passed through the soil to re-dissolve the precipitated salt. The sum of the difference in concentrations is therefore greater than expected when the solubility limit is exceeded, and is thus no longer a linear function of impulse magnitude. In practice, it is unlikely that emissions would be released that would result in the solubility limit being exceeded, or at the very least, the environmental authorities would prevent this. The remainder of the analysis was therefore done with an impulse magnitude of $1 \times 10^{8} \mathrm{~kg}$.

\section{Impulse duration}

The effect of impulse duration was determined by keeping the impulse magnitude and impulse starting date constant, at $1 \times 10^{8} \mathrm{~kg}$ and 1 January 2002 respectively. The impulse duration was varied and the effect on the effects potentials determined. It was found that for impulse durations of less than one year, effects potentials vary with impulse duration, but for impulse durations of greater than one year, there is very little variation in effects potentials. This is due to the fact that for impulse durations of less than one year, seasonal variations in hydrological parameters, such as rainfall and evaporation, will influence the distribution of salts, whereas over one hydrological cycle (one year), this is not the case. It is unlikely that an environmental life cycle assessment of an activity occurring 


\begin{tabular}{|c|c|c|c|c|c|c|c|c|c|}
\hline \multicolumn{10}{|c|}{$\begin{array}{c}\text { TABLE 7 } \\
\text { Effects potentials and total salinity potentials }\end{array}$} \\
\hline $\begin{array}{l}\text { PNEC }\left(\mathrm{kg} / \mathrm{m}^{3}\right) \\
\text { Weighting factor }\end{array}$ & $\begin{array}{c}1.15 \mathrm{PEC} \\
1\end{array}$ & $\begin{array}{c}0.46 \\
1\end{array}$ & $\begin{array}{c}0.98 \\
1\end{array}$ & $\begin{array}{c}1.00 \\
1\end{array}$ & $\begin{array}{c}1.20 \\
1\end{array}$ & $\begin{array}{c}0.10 \\
1\end{array}$ & $\begin{array}{c}0.45 \\
1\end{array}$ & & \\
\hline \multicolumn{10}{|c|}{ Effects potentials (kg TDS equivalent/kg) } \\
\hline $\begin{array}{l}\text { Initial release } \\
\text { compartment }\end{array}$ & $\begin{array}{c}\text { AEEP } \\
\text { (aquatic } \\
\text { ecotoxicity) }\end{array}$ & $\begin{array}{c}\text { ACEP } \\
\text { (agricultural } \\
\text { crops) }\end{array}$ & $\begin{array}{c}N V E P \\
\text { (natural } \\
\text { vegetation) }\end{array}$ & $\begin{array}{c}L E P \\
\text { (livestock) }\end{array}$ & $\begin{array}{l}N W E P \\
\text { (wildlife) }\end{array}$ & $\begin{array}{c}M D P \\
\text { (material } \\
\text { damage) }\end{array}$ & $\begin{array}{c}\text { AeEP } \\
\text { (aesthetic) }\end{array}$ & $\begin{array}{c}\text { TSP } \\
\text { (total } \\
\text { salinity } \\
\text { potential) }\end{array}$ & $\begin{array}{c}\text { Contri- } \\
\text { bution } \\
\text { (\%) }\end{array}$ \\
\hline Atmosphere & 0.00028 & 0.00754 & 0.00040 & 0.00034 & 0.00028 & 0.00336 & 0.00075 & 0.01294 & 1.07 \\
\hline River & 0.00397 & 0.09824 & 0.00000 & 0.00443 & 0.00369 & 0.04432 & 0.00985 & 0.16450 & 13.61 \\
\hline Rural natural surface & 0.00067 & 0.01792 & 0.00102 & 0.00081 & 0.00068 & 0.00810 & 0.00180 & 0.03100 & 2.57 \\
\hline Rural agricultural surface & 0.00027 & 0.99523 & 0.00000 & 0.00032 & 0.00027 & 0.00320 & 0.00071 & 1.00000 & 82.75 \\
\hline Total & 0.00519 & 1.11894 & 0.00142 & 0.00590 & 0.00491 & 0.05898 & 0.01311 & 1.20844 & \\
\hline Contribution (\%) & 0.43 & 92.59 & 0.12 & 0.49 & 0.41 & 4.88 & 1.08 & & \\
\hline
\end{tabular}

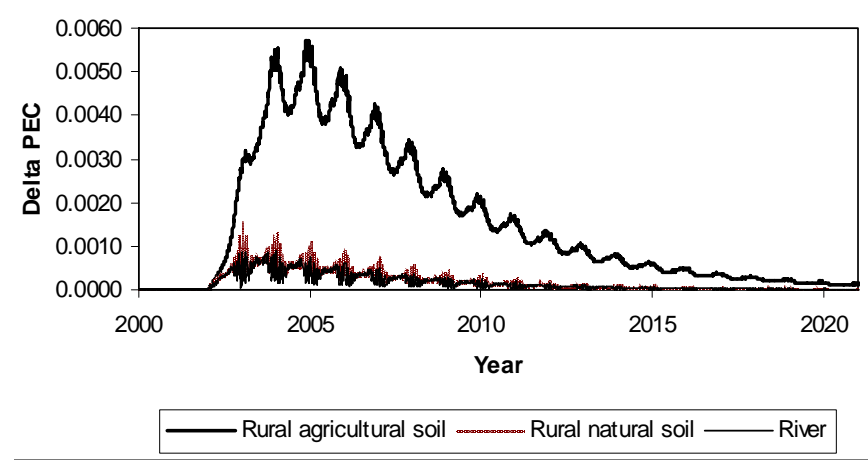

Figure 9

Delta PEC for an emission impulse onto the rural natural surface

over a time period of less than one year would be conducted. The salinity potentials are therefore independent of the duration of the impulse emission.

\section{Impulse start date}

The effect of impulse start date was evaluated by keeping the impulse magnitude and impulse duration constant, at $1 \times 10^{8} \mathrm{~kg}$ and one year respectively, and varying the starting date of the impulse. The results of the evaluation showed that salinity potentials were independent of impulse start date

\section{Simulation length}

The next important factor to be considered when calculating the effects potentials is the simulation length. The duration of the simulation must be sufficient to allow the difference in predicted environmental concentrations (with and without an emission impulse) to approach zero. The concentration differential in the soil compartments took the longest to approach zero. Figure 9 shows the difference in predicted environmental concentrations (indicated as Delta PEC on the figures) for the soil compartments as a function of time over a 20 -year period. It is evident that the difference in predicted environmental concentrations (with and without an imposed emission impulse) is approximately zero after
20 years. The salinity effects potentials can therefore be regarded as infinite time horizon potentials.

\section{Effects potentials and total salinity potentials}

Effects potentials were therefore calculated from a 20-year simulation, with an impulse magnitude of $1 \times 10^{8} \mathrm{~kg}$, of one-year duration, starting on 1 January 2001. The effects potentials have been normalised so that the total salinity potential for emission onto agricultural soil is equal to unity. The normalised effects potentials are shown in Table 7 . The effects potentials and total salinity potential are therefore expressed as kg TDS equivalents per $\mathrm{kg}$ TDS, and are for an infinite time horizon.

The totals of the vertical columns of Table 7 represent the effects potentials if emissions occur into each initial release compartment simultaneously. It is evident that, for all weighting factors set equal to unity, potential effects on agricultural production far outweigh any of the other potential salinity effects, followed by material damage effects.

It is evident that the total salinity potential for emissions onto the rural agricultural surface by far outweighs (82.8\%) the salinity potentials for releases into other compartments, followed by the salinity potential for emissions into the river (13.6\%), onto rural natural surfaces (2.6\%) and into the atmosphere (1.1\%). Salination is recognised as one of the major threats to the water resources of South Africa, along with eutrophication, microbial contamination, erosion and acidification. The major contributors to salination in South Africa are attributed to municipal and industrial wastes, urban storm-water runoff, irrigation return water, seepage from mining activities and solid waste disposal sites. Rapid population growth has led to urbanisation, intensification of agricultural production, and industrialisation. Furthermore, government policies that have encouraged monoculture and intensive use of agrochemicals have resulted in over-use of the land, and degradation of vegetation and soils. Approximately 54000 ha of agricultural land has been severely affected by salination, and approximately 128000 ha moderately affected. Approximately $10 \%$ of the irrigated land in South Africa is severely affected by salination. The conversion of natural ecosystems for intensive agricultural or forestry production, or for grazing purposes, have been identified as major pressures on plant diversity in the country (DEAT, 1999). 
The Department of Water Affairs and Forestry have implemented a policy, which is enshrined in the National Water Act (DWAF, 1998), that discourages the irrigation of water containing wastes, and which classifies the irrigation of water containing wastes as a scheduled process, to which certain conditions apply. The salinity potentials support this policy.

For almost 40 years, South Africa has subscribed to the policy of managing water quality through returning water to its source, and setting effluent standards. Even though these standards were largely adhered to, the quality of receiving water bodies deteriorated, and the policy has now changed to one of management according to receiving water quality objectives, aimed at maintaining the ecological functions of the aquatic ecosystems (DEAT, 1999). The salinity potential for emissions into the river is the second highest which appears to support the move towards managing water resources through the setting of receiving water quality objectives. If one looks at the effects potentials, however, the potential salinity effects are greatest on agricultural crop production, followed by material damage effects. Aquatic ecotoxicity effects rank second last, and are lower than potential aesthetic effects. In reality, aquatic ecotoxicity effects could indeed be low compared to other effects. In a study conducted by the Water Research Commission on the economic cost effects of salinity (WRC, 2000a) in the middle Vaal River area, the highest direct cost of salinity was to the household sector (due to material damage effects), followed by the manufacturing sector. Direct costs of salinity to the agricultural sector ranked the lowest (in part, due to the salt-tolerant crops grown in the middle Vaal catchment). Unfortunately the study concluded that the cost effects on the natural environment could not be determined, and were not included. The results of the study do, however, indicate that material damage has significant cost implications, supported by the material damage effects potentials, which rank second in their contribution to total effects potentials. It should be borne in mind that doseresponse data for salinity on aquatic organisms are very limited. It is therefore not known if the guidelines recommended by the Department of Water Affairs and Forestry (1996) $(<15 \%$ increase in total dissolved salts concentration) are over- or under-protective.

By examining the salinity potentials, one could deduce that the most environmentally benign way of disposing of salts would be to release them into the atmosphere; particularly if emissions are above stable inversion layers. A large portion of the salt released in this way will be transported offshore, and deposition will take place over a larger area. It should, however, be borne in mind that the atmospheric model developed is very simplistic, and assumes complete mixing in the urban and rural air volumes. In reality, localised areas of high concentration will occur in the vicinity of the emission, which will result in far greater localised deposition rates, which in turn may result in greater surface and sub-surface water salt concentrations. In addition, human health effects are not taken into account in the calculation of salinity potentials. Large emissions into the atmosphere may result in localised aerosol concentrations that exceed safe levels. The second lowest contributor to total salinity potential results from emissions to rural natural land. This is obviously not a practical method for the disposal of salts, since even distribution of the salts over the entire rural natural area would be required.

The results and discussion presented above are for effects potentials having equal weights. Weighting factors can be used to determine the relative importance (or value) of the salinity subimpacts considered (effects potentials). One could, for example, weight potential aesthetic effects as being half as important as material damage effects, and so on. These choices are, for the time being, subjective, and will remain so until a scientifically valid method for expressing potential effects in a common currency have been developed. It is therefore recommended that, until such a method is developed, equal weightings be assigned to the effects potentials. The work done by the Water Research Commission on the economic cost effects of salinity (WRC, 2000a) are a step in the direction of being able to determine the relative weighting, based on economic considerations. Ideally, weightings should be based on social, economic, and ecological considerations.

\section{Conclusions and recommendations}

In terms of the environmental fate model the following conclusions and recommendations are made:

- The non steady-state hydrosalinity model developed was based on existing models that are well accepted and are in general use in South Africa. Many of the model parameters are available for all catchments in the country at quaternary catchment level, making the definition of the "unit catchment" and the calibration of the model relatively simple. A simple non steady-state atmospheric deposition "box-model" was therefore developed to predict aerosol (and associated salt) deposition at a daily time-scale, in accordance with the daily time-step hydrosalinity model. Some simplifying assumptions were made in the development of the atmospheric deposition model that are clearly a great simplification of what actually occurs in nature. The atmospheric deposition model cannot be calibrated at a daily time-step due to the lack of data. However, model outputs are in the same order of magnitude as the (limited) published data. In addition, most of the model parameters used do not affect the value of the fate factors, and those parameters that do, do not have a major effect on the value of the fate factors. It is not recommended that complex atmospheric dispersion models be developed. These models require a large number of parameters, and it is doubtful that such models could be developed for a "unit South African environment”. It is, however, recommended that more data be collected to refine the model parameters used (particularly the fraction of salt associated with aerosols), and that more data be collected that will enable better calibration of the model.

- Predicted surface water flow and quality correlate well with calculated values for the "unit catchment" as defined. There is however a degree of uncertainty and variability in the calculated values for the "unit catchment", and therefore in the fate factors, and ultimately the salinity potentials. It is recommended that the method used to calculate the average monthly surface water quality be refined, and that uncertainty and variability in the data be quantified, with the aim of quantifying the variability and uncertainty associated with the calculated salinity potentials.

- Simple parameter sensitivity analyses were performed on the various components of the overall model, in an attempt to identify the sensitive model parameters and refine the model calibration. The sensitivity of model outputs to the model parameters varied is understood, and agrees with expected behaviour. The parameter sensitivity analyses are, however, by no means exhaustive, and it is possible that the same level of agreement between predicted and observed (calculated for the "unit catchment") can be achieved with a different set of model parameters. The approach adopted in calibrating the model is sound. However, it is recommended that more detailed sensitivity analyses be conducted using multi-variate statistical 
techniques to refine the model calibration.

- Some model parameters (particularly those that influence the distribution of surface and subsurface flow) do influence the values of the fate factors (and therefore the salinity potentials). It is recommended that more data be collected to refine these parameters.

- For a number of reasons, salts were modelled as a lumped parameter (total dissolved salt) and therefore certain model parameters (such as solubility limit, and adsorption constants) are also lumped parameters. It is recommended that the common ions be modelled separately and that separate salinity potentials be calculated for each ion. This would however require some level of speciation to be built into the model, and at this stage, some data are not available, most notably the adsorption constants for individual ions. This data would therefore need to be collected.

- The assumption made in the characterisation model is that all water for livestock watering and domestic use is taken from surface water. In reality, a (small) portion of water for these users is taken from groundwater. It is recommended in future that this be included in the model.

The effect factors used in the characterisation model were based on the target water quality ranges given by the South African Water Quality Guidelines (DWAF, 1996). It is well known that there is a severe lack of dose-response data for South African species, particularly for aquatic organisms. As these data become available, the model developed could be refined.

Regarding the use of the salinity potentials in conducting environmental life cycle assessment, the following should be borne in mind:

- The salinity potentials are only relevant to South African conditions, and their use in LCA in other countries may not be applicable. This, in effect, means that the life cycle activities that generate salts should be within the borders of South Africa. It has been recognised that the LCA methodology requires greater spatial differentiation. Salination is a local or regional problem, and it is foreseen that local or regional salinity potentials would need to be calculated for different areas of the earth where salinity is a problem. The LCA practitioner would need to know something about the spatial distribution of LCA activities in order to apply the relevant salinity potentials.

- The LCA practitioner should take care when applying the salinity potentials to prevent double accounting for certain impacts. Currently, this is simple because no equivalency factors exist for common ions, or for total dissolved salts as a lumped parameter.

- The LCA practitioner is also required to have some knowledge about the nature of salts emitted into the atmosphere when generating the life cycle inventory and applying the salinity potentials. Not all matter emitted into the atmosphere will be deposited as salt.

- The various salinity potentials that make up the total salinity potential have, in the absence of better information, all been given equal weight. Weighting of the salinity potentials will be based on subjective value judgments and should include input from policy makers in the country. It is recommended that a method be developed to weight the salinity potentials.

The distribution of salinity potentials, which make up the total salinity potential, appears to be supported by the environmental policies and legislation of South Africa.
The work presented focuses on a method for incorporating salinity impacts into environmental life cycle assessment, and presents salinity potentials to do this. There is currently no way of normalising or weighting the LCA results for South Africa. Methods to do this still need to be developed.

The values of the published equivalency factors are dependent on the mathematical definition of the local or regional environment, and these values have been calculated for Western European conditions. Equivalency factors may vary by several orders of magnitude, depending on how the local or regional conditions have been defined. It is therefore recommended that the model developed in this work be included into a global nested model, in the same way as the USES-LCA model, to calculate equivalency factors for other compounds, including heavy metals and organic compounds. This would result in equivalency factors for all compounds that are relevant to South Africa.

\section{References}

ANDERSON EE, GRANT WB GREGORY GL, BROMWELLI EV, COLLINS JE, SACHSE GW, BAGWELL DR, UDGINS CH, BLAKE DR and BLAKE NJ (1996) Aerosols from biomass burning over the tropical South Atlantic region: Distributions and impacts. J. Geophys. Res. 101 (D19).

BRIDGEMAN H (1990) Global Air Pollution: Problems for the 1990s. Belhaven Press, London.

COLEMAN T (1993) Urban Runoff Quality and Modelling Methods. WRC Report No. 183/10/93. Water Research Commission, Pretoria. South Africa.

DEAT(DEPARTMENT OF ENVIRONMENTAL AFFAIRS ANDTOURISM) (1999) State of the Environment Report. Available on-line at: http://www.ngo.grida.no.

DE NEVERS N (1995) Air Pollution Control Engineering. McGraw-Hill International Editions. McGraw-Hill Book Company. Singapore.

DWA (DEPARTMENT OF WATER AFFAIRS) (1986) Managing of the Water Resources of the Republic of South Africa. Department of Water Affairs. Pretoria. South Africa.

DWAF (DEPARTMENT OF WATER AFFAIRS AND FORESTRY) (1995) Procedures to Assess Effluent Discharge Impacts. Water Research Commission Report No. TT 64/94. Water Research Commission, Pretoria, South Africa.

DWAF (DEPARTMENT OF WATER AFFAIRS AND FORESTRY) (1996) South African Water Quality Guidelines. Vol 1 to 6. Pretoria, South Africa.

DWAF (DEPARTMENT OF WATER AFFAIRS AND FORESTRY) (1998) National Water Act. Available on-line at: http:// www.dwaf.gov.za.

EC (EUROPEAN COMMISSION) (1996) Technical Guidance Documents in Support of Commission Directive 93/67/EEC on Risk Assessment for New Notified Substances and Commission Regulation (EC) No. 1488/94 on Risk Assessment For Existing Substances. Part II. EC catalogue numbers CR-48-96-002. Office for Official Publications of the European Community, 2 rue Mercier, L-2965 Luxembourg.

HEROLD CE (1981) A Model to Simulate Daily River Flows and Associated Diffuse-Source Conservative Pollutants. Report No 3/81. Hydrological Research Unit. University of the Witwatersrand. Department of Civil Engineering. Johannesburg, South Africa.

HEROLD CE, TAVIV I and PITMAN WV (2001) Modelling of Long-term Effect of Atmospheric Deposition on the Salinity of Runoff From the Klip River Catchment. WRC Report No. 697/1/01. Water Research Commission, Pretoria. South Africa.

HEWITT CN and STURGES WT (1993) Global Atmospheric Chemical Change. Elsevier Science Publishers LTD. Essex, England.

HUGHES DA (1997) South African "FRIEND”- The Application of Rainfall-Runoff Models in the SADC Region. WRC Report No. 235/ 1/97. Water Research Commission. Pretoria. South Africa.

HUIJBREGTS MA (1999) Priority Assessment of Toxic Substances in the Frame of LCA. Development and Application of the Multi-media 
Fate, Exposure and Effect Model USES-LCA. University of Amsterdam. Faculty of Environmental Sciences. Amsterdam. Netherlands.

LESKE A (2003) The Development of a Method for the Inclusion of Salinity Effects into Environmental Life Cycle Assessment. School of Chemical Engineering. University of Natal - Durban, Durban, South Africa.

LESKE A and BUCKLEY CA (2003) Towards the development of a salinity impact category for South African environmental life cycle assessments: Part 1 - A new impact category. Water SA 29 (3) 289296.

LESKE A and BUCKLEY CA (2004) Towards the development of a salinity impact category for South African environmental life cycle assessments: Part 2 - Conceptual multimedia environmental fate and effect model. Water $S A 30$ (2)

MAAS EV (1990) Crop salt tolerance. Agricultural Salinity Assessment and Management. American Society of Civil Engineers. New York.

MAENHAUT W, SALMA I, CAFMEER J, ANNERGARN HJ and ANDREAEMO (1996) Regional atmospheric composition and sources in the Eastern Transvaal, South Africa, and impact of biomass burning. J. Geophys. Res. 101 (D19).

MIDGLEY DC, PITMAN WV and MIDDLETON BJ (1994) Surface Water Resources of South Africa. WRC Report No. 298/1/94. Vol I to VI. Water Research Commission. Pretoria, South Africa.

MOOLMAN JH (1993) An Evaluation of a Range of Computer Models Simulating the Transport of Solutes and Water in the Root Zone of Irrigated Soils. WRC Report No. 196/1/93, Water Research Commission, Pretoria. South Africa.

PALING WAJ, STEPHENSON D and JAMES CS (1989) Modular Rainfall-Runoff and Erosion Modelling. Water Systems Research Programme Report No. 1/1989. Department of Civil Engineering. University of the Witwatersrand. Johannesburg. South Africa.
PIKETH SJ, SWAP RJ, ANDERSON CA, FREIMAN MT, ZUNKEL M and HELD G (1999) The Ben Macdhui high altitude tracer gas and aerosol transport experiment. S. Afr. J. Sci. 95 (Jan).

PITMAN WV (1973) A Mathematical Model for Generating River Flows from Meteorological Data in South Africa. Hydrological Research Unit. Report No. 2/73. University of the Witwatersrand. Johannesburg. South Africa.

PITMAN WV (1976) A Mathematical Model for Generating Daily River Flows from Meteorological Data in South Africa. Report No 2/76. Hydrological Research Unit. University of the Witwatersrand. Department of Civil Engineering. Johannesburg, South Africa.

PYE K (1994) Sediment Transport and Deposition Processes. Blackwell Scientific Publications, Oxford, England.

SKOROSZEWSKI RW (1999) The Relationship Between Atmospheric Deposition and Water Quality in a Small Upland Catchment. Water Research Commission Report No. 421/1/99. Water Research Commission, Pretoria. South Africa.

TYSON PD and GATEBE CK (1996) The atmosphere, aerosols, trace gases and biochemical change in Southern Africa: A regional integration. S. Afr. J. Sci. 79 (March).

TYSON PD, GARSTANG M, SWAP R, KALLBERG P and EDWARDS M (1996) An Air transport climtology for subtropical Southern Africa. Int. J. Climatol. 16.

WRC (WATER RESEARCH COMMISSION) (2000a) The Economic Cost Effects of Salinity: Integrated Report. Report No. TT 123/00. Water Research Commission, Pretoria. South Africa.

WRC (WATER RESEARCH COMMISSION (WRC) (2000b) The Economic Cost Effects of Salinity: Integrated Report. Report No. TT 123/ 00. Water Research Commission,Pretoria. South Africa. 